\title{
RELATIONSHIP BETWEEN BIOCHEMICAL ENERGY RESERVES AND SOME ECOLOGICAL TRAITS OF THREE SPECIES OF ENTOMOPATHOGENIC NEMATODES
}

\author{
SAMI S. EL- BADAWY
}

Plant Protection Research Institute, ARC, Dokki, Giza, Egypt

(Manuscript received 22 December 2010 )

\begin{abstract}
The biochemical energy reserves of three species of entomopathogenic nematodes (EPN) were analysed quantitatively at three infective juvenile ages 0, 20 and 90 days for Steinernema (Steinernema riobrave), less than 7, 30 and 50 days and 0, 20 and 40 days for Heterorhabditis (Heterorhabditis bacteriophora and Heterorhabditis indica) respectively. Lipid, protein, carbohydrates and glycogen contents of the two species of Heterorhabditis and one species of Steinernema were determined. Results revealed that total lipids are the main component, comprising approximately 42.55 of nematode dry weight for $S$. riobrave and $50.52 \%, 53.75 \%$ for $H$. bacteriophora and $H$. indica, respectively, when freshly emerged from their hosts. These percentages declined significantly at the other two juvenile ages of the three species. Glycogen and protein contents in all species exhibited minor changes during the tested juvenile ages. Estimation of total carbohydrates appeared to be source of energy that only utilized early in the ambushing state of $S$. riobrave and when juveniles get older in $H$. indica and $H$. bacteriophora. Infectivity of the three nematode species at the three tested ages was not affected, where approximately $100 \%$ Galleria mellonella mortality was recorded except a slight insignificant decrease $(97.33 \%)$ in $H$. indica at the age of 40 days. Penetration rate of $H$. indica, and $H$. bacteriophora decreased with the declining of the total lipid content at the three juvenile ages, while the penetration rate in $S$. riobravae exhibited significant decrease only at 90-day old juveniles. Significant decreases in migration rate were evident in $H$. indica and $H$. bacteriophora as the total lipid content declined in the juvenile ages. These results might be helpful in increasing the efficiency of EPN as biological control agents against insect pests by improving shelf-life of nematode juveniles and establishing a simple and easy quality control method for different nematode species or strains.
\end{abstract}

Key Words: Entomopathogenic nematodes, Steinernema, Heterorhabditis, energy reserves and ecological traits.

\section{INTRODUCTION}

Since the nematodes free-living infective juveniles are non-feeding, the stored energy reserves in these juveniles are of most important. Some energy reserves of the nonfeeding nematode juveniles have been reported to play important roles in their life. Infective juveniles (IJs) of entomopathogenic nematodes (EPN) do not feed but have ample stored energy reserves and can survive for several months in soil or in 
water, (Fitters and Griffin 2006). Factors of major importance are age and lipid reserves of infective juveniles (IJs). Energy reserves, particularly neutral lipids, are an important indicator of quality (infectivity and motility) of stored nematodes. Lipids, carbohydrate (especially glycogen), and protein, accumulated during the preceding juvenile stages within the host, all provide energy for IJs during storage, (Qiu and Bedding 2000). Lipids can be used to predict nematode quality and nematode shelflife, (Abu-Hatab and Gaugler 1997a). Lewis et. al. (1995) studied the relationship between the metabolic rate, energy reserves, and foraging in three species of EPN (Steinernema carpocapsae, Steinernema glaseri and $H$. bacteriophora). Their studies showed that stored lipids are the major component of nematode energy reserves and declined at species-specific rates. Fitters et. al. (1997) noted that, during storage, non-feeding stages of EPN (S. carpocapsae and two strains of Heterohabditis) became visibly more transparent due to depletion of energy reserves.

The present investigation aims to analyse energy reserves (Lipids, carbohydrates protein and glycogen) of the two species of Heterorhabditis and one species of Steinernema during three different ages. The correlation between the biological and ecological traits virulence, penetration rate and migration rate of EPN during the indicated ages, and the results of the chemical analysis.

\section{MATERIALS AND METHODS}

\section{Nematode Source}

The three species $H$. bacteriophora, $H$. indica and $S$. riobrave were obtained from the Laboratory of Insect Parasitic Nematodes, Plant Protection Research Institute. Nematodes were reared on last instar $G$. mellonella (L.) as a host at $25^{\circ} \mathrm{C}$ according to procedures described by (Kaya and Stock 1997). Nematode juveniles at the tested ages were used for the following ecological and biochemical tests after being stored at $15^{\circ} \mathrm{C}$.

\section{Ecological Traits}

Nematode infective juveniles of the three species at the three ages $(0,20$ and 90 days) for $S$. riobrave; less than one week, 30, 50 days and $0,20,40$ days for. $H$. bacteriophora and $H$. indica, respectively, were tested for the following ecological activities:

\section{1- Infectivity}

Full grown larvae of $G$. mellonella kept in $1.5 \mathrm{ml}$ Eppendorf tubes, lined with double layer filter paper (Whatman No. 1), were subjected to nematode infection at a dose level of $40 \mathrm{IJs} /$ larva in $300 \mu \mathrm{l}$ distilled water and kept at $25^{\circ} \mathrm{C}$, in the dark. For 
each of the tested nematode ages, 3-5 replicates, (each of 10 larvae), in addition to a control treatment containing only distilled water. Mortality records were taken after 48 hours and corrected according to Abbot's formula (Abbott 1925).

\section{2- Penetration rate}

At each of the tested nematode ages, G. mellonella larvae, having the signs of nematode infection in the virulence test, were washed twice with distilled water to remove any nematode juveniles attached to them, dried and dissected under a stereomicroscope. The number of nematodes inside each larva was counted and the penetration rate was calculated as an average in at least 20 larvae, (Abd El-Rahman 2001).

\section{3- Dispersal rate (Migration rate)}

The T-tube choice system described by Abd El-Rahman (2001) was followed to study $H$. bacteriophora and $H$. indica migration rate at the tested ages.

\section{Determination of Main Energy Reserves in Nematode Juveniles}

\section{1-Total lipids}

Nematode juveniles (0.05-0.1g) were washed by water and incubated in $15 \mathrm{ml}$ ethanol $80 \%$ at $75^{\circ} \mathrm{C}$ for five minutes to inactivate degradative enzymes such as phospholipases. The suspension was cooled and stored in a tight-capped tube after flushing with $\mathrm{N}_{2}$, and stored at $-70^{\circ} \mathrm{C}$, (Abu Hatab and Gaugler 1997a). Lipids were extracted and purified according to (Folch et. al. 1957). Total lipids were determined according to (Knight et. al. 1972). Lipid content expressed as $\mu \mathrm{g} / \mathrm{g}$ nematode was calculated using a standard curve (oleic and palmetic acids).

\section{2- Total proteins}

Proteins were extracted from nematode tissue and prepared for assay as reported by Lewis et al. (1995). Nematode sample $(0.05 \mathrm{~g})$ was homogenized with $7 \mathrm{ml} \mathrm{KOH}$ $30 \%$ and boiled for 1 hour with occasional agitation. Protein content of nematode samples was estimated spectro-photometrically by the method of (Bradford 1976). Protein content in nematode homogenate was expressed as $\mu \mathrm{g}$ protein/g body weight using bovine serum albumin standard curve.

\section{3-Total carbohydrates}

Carbohydrates were extracted from nematode tissues and prepared for assay as described by (Lewis et. al. 1995). Carbohydrates content was determined by phenolsulfuric acid reaction according to (Dubois et. al. 1956). Total carbohydrates content were calculated according to glucose standard and are expressed as $\mu \mathrm{g}$ glucose $/ \mathrm{g}$ body weight. 


\section{4-Glycogen content}

Glycogen was precipitated from nematode homogenate $(0.05 \mathrm{~g}$ in $7 \mathrm{ml} 30 \% \mathrm{KOH})$ with $1 \mathrm{ml}$ ethanol and the mixture was kept at $-15^{\circ} \mathrm{C}$ overnight. The precipitation was sedimented by centrifugation at 15,000 rpm for 5 minutes, redispersed in $4 \mathrm{ml}$ ethanol and resedimented, the washed precipitate was dried at $105^{\circ} \mathrm{C}$ and dissolved in $2 \mathrm{ml}$ distilled water for determination, (Lewis et. al. 1995). Glycogen content of nematode was estimated spectrophotometrically by phenol-sulphuric acid reaction according to (Dubois et. al. 1956). Glycogen content was expressed as $\mu \mathrm{g}$ glucose/g body weight using glucose standard curve.

\section{Statistical Analysis}

Data presented in percentage values in the present study were normalized using arcsine transformation. The significance of the main effects was determined by analysis of variance (ANOVA). The significance of various treatments was evaluated by Duncan's multiple range test $(P<0.05)$. All analyses were made using a software package "Costat", a product of Cohort Software Inc., Berkeley, California, U.

\section{RESULTS AND DISCUSSION}

\section{Ecological Traits}

\section{1-Nematode virulence}

Infectivity of the three species at the three tested ages did not change significantly through the experimental period for $S$. riobrave and $H$. bacteriophora, nearly $100 \%$ mortality was recorded in $G$. mellonella larvae subjected to infection at a rate of $40 \mathrm{IJs} /$ larva. Insignificant decrease in $\mathrm{H}$. indica infectivity at the age of 40 days (97.33\% G. mellonella mortality) was evident (Table 1).

\section{2- Penetration rate}

Penetration rate exhibited significant decrease from $25.01 \%$ at 0 -day old juveniles to $22.80 \%$ at 90 -day old juveniles for $S$. riobrave (Table 2 ). The decrease in penetration of $\mathrm{H}$. indica juveniles was much obvious, where a gradual decrease was recorded at the three ages $(21.70,13.00$ and $11.50 \%$, respectively). Significant decreases in juvenile penetration rate were evident with $H$. bacteriophora after 30 and 50 days of storage at $25^{\circ} \mathrm{C}$. The recorded values of penetration rate at these ages were 8.55 and $7.05 \%$, respectively, opposed to $40.09 \%$ for IJs less than seven days old. In the present investigation, the number of penetrating nematodes decreased as IJs go older, similar results were reported by El-Bishry et. al. (2002) who reported that penetration rate of four isolates of the nematode Heterorhabditis spp. decreased significantly as juveniles get older. Also confirmed by Corrie et. al. (2004) who found 
that age and species effects were noted in G. mellonella mortality and nematode penetration during shorter time periods. Initial mortality caused by $S$. carpocapsae and $H$. bacteriophora IJs declined with nematode age. Young $S$. carpocapsae IJs penetrated $G$. mellonella larvae at higher rates than older individuals of the species ( $27-45 \%$ vs. $1-4 \%)$.

\section{3- Migration rate}

Migration rate and the distance traveled by $H$. bacteriophora was significantly different

in juveniles of less than seven days old and those of 30 days old (Table 3). Migration rates were 98.88 and $78.77 \%$ of the total nematode population and the distances covered by these juveniles were $9.50 \mathrm{~cm}$ and $8.0 \mathrm{~cm}$. In the contrary, these values were much reduced at 50 days old, where migration rate significantly decreased to $38.40 \%$ and the distance covered by nematode juveniles was only $1.90 \mathrm{~cm}$. Similarly, results of migration rate of $H$. indica went in the same line. Percent of migrating juveniles was $96.55 \%$ in 0-day old IJs; covering a distance of over $9 \mathrm{~cm}$ (Table 3). This percentage was decreased significantly to less than $30 \%$ for 20 -day old juveniles; and to $15.97 \%$ at 40 day old IJs with distances $2.80 \mathrm{~cm}$ and $1.10 \mathrm{~cm}$ respectively. Migration and host-finding ability of Heterorhabditis species are essential processes in their success as biological control agents. So, juvenile age is very important factor that should be taken into consideration when using these nematodes to control a certain pest.

\section{Biochemical Analysis of Energy Reserves:}

\section{1- Total lipids}

Data illustrated in table (4) showed that percentages of total lipids were $42.55,50.52$ and $53.75 \%$ of nematode dry weight for $S$. riobrave, $H$. bacteriophora and $H$. indica respectively, when freshly emerged from their hosts ( 0 day old) for $S$. riobrave and $H$. indica, and less than one week for $H$. bacteriophora. These results are in agreement with those reported by Lewis et. al. (1995) where total lipids comprised $36-40 \%$, also they reported that stored lipids were the major component of nematode energy reserves in these members of entomopathogenic nematodes. Abu Hatab and Gaugler (1997a) reported that lipid content in the nematode $S$. riboravis was up to $43.4 \%$ per dry weight, Also, Fitters et. al. (1997) found that the percentage of total lipids of $S$. carpocapse and two Heterorhabditis isolates (UK211 and HF85) was similar for two isolates when freshly emerged from cadaver (35-39\%). Lipid is the main energy reserve, constituting between 32 and 49\% of IJs body weight Lewis et. al. (1995) and Menti et. al. (2003). El-Assal et. al. (2008) reported that total lipid content in original S. riobrave and $H$. bacteriophora recorded 39.1 and $41.3 \%$ respectively. Higher 
percentages of lipid content were reported by Shapiro et. al. (2005) where they demonstrated that total lipids content of two species of EPN ( $S$. carpocapsae and $S$. riobrave) ranged from 48 to $84 \%$ according to the cultured host and method These percentages declined significantly to nearly $22-45 \%$ after 30 days, and to $16.00 \%$ after 50 days of storage for $H$. bacteriophora. This is similar to the percentages reported by El-Badawy (2002) total lipid percentages of $H$. bacteriophora declined significantly from $45 \%$ when freshly emerged from their hosts (less than one week) to nearly $19-20 \%$ after 30 days, and to $11-12 \%$ after 50 days of storage and Lewis et. al. (1995) in another strain of the same species (18-20\%) and (13-15\%) after 4 weeks and 7 week respectively. In case of $H$. indica, these percentages decreased to $37.39 \%$ after 20 days, and to $25.55 \%$ after 40 days of storage. Radwan (2002) showed that the percentage of total lipids content declined significantly from $54.75 \%$ (0-day) to $39.39 \%$ after 20 days, and to $26.51 \%$ after 40 days of storage in H. indica.

On the other hand the total lipid content of $S$. riobrave IJs, was nearly the same during the first 20 days of their life (42.0\%). A sharp significant decrease was recorded after 90 days of storage, where the recorded value was $18.00 \%$. This is confirmed by Lewis et. al. (1995) they reported that total lipids declined at speciesspecific rates. This means that infective juveniles of entomopathogenic nematodes are capable of adjusting their lipid content at different periods of life. The above results refer that the infective juveniles of $H$. bacteriophora nematodes consumed more than $70 \%$ of lipid reserves during 50 days of their life. In other words, nematode juveniles of $H$. indica and S. riobrave consumed more than $50 \%$ of lipid reserves during 40 and 90 days of their life respectively. Lewis et. al. (1995) reported that $H$. bacteriophora IJs used approximately $60 \%$ of their total lipids during 7 weeks of storage. Menti et. al. (2003) stated that, NL (neutral lipids) of both S. feltiae populations decreased by ca $60 \%$ during the first 4 weeks but remained more or less stable during the next 16 weeks. In the two Heterorhabditis species, NL decreased by ca $70 \%$ during the first 4 weeks and continued to decrease, with $3-5 \%$ remaining after 12 weeks. Chemical analysis of nematode juveniles at the indicated ages suggests that, total lipids are the main source of energy. Lewis et. al. (1995) found that stored lipids are the major component of nematode energy reserves in members of Steinernema spp. Abu Hatab and Gaugler (1997a) reported that the high lipids content of $S$. riobrave suggests that these compounds are the chief food reserve for infective juveniles.

\section{2- Total proteins}

Data represented in table (5) showed that protein contents in all species exhibited minor changes during the tested juvenile ages. Protein percentage remained 
constant during the three inspection periods (approximately $11 \%$ of nematode dry weight for $S$. riobravae and $H$. bacteriophora and $12 \%$ for $H$. indica). Therefore, this component might play minor role as an energy reserve in this nematode species. These results are confirmed by Lewis et. al. (1995) since they found that the level of protein content remained constant for all species ( $S$. carpocapsae, S. glaseri and $H$. bacteriophora) at approximately $12.2 \%$ throughout the study.

\section{3- Total carbohydrates}

Estimation of total carbohydrates table (6) revealed the importance of this energy reserve in the nematode $S$. riobrave. In fact, they might the only main source of energy during the first 20 days. Total carbohydrate content decreased significantly from $23.43 \%$ at 0 -time to $16.33 \%$ of nematode dry weight after 20 days. Another decrease, but insignificant, was also evident at 90-day old juveniles (14.28\%). Lewis et. al. (1997) provided some evidence that in some cases Steinernema species changed their foraging strategy for infecting a host from ambushers to cruisers (active seekers for host). It seems that nematode juveniles during the ambushing state depended mainly upon carbohydrates as energy reserves because they actually stayed motionless waiting for passing by hosts. When they changed their searching strategy to be cruisers where richer sources of energy were needed; they began to utilize their lipid content.

In case of $H$. indica, during the first 20 days total carbohydrates declined from 13.94 to $11.84 \%$ of nematode dry weight. At 40 -day old juveniles, total carbohydrates decreased to comprise 8.25. Total carbohydrates content of $H$. bacteriophora might play minor role as energy reserves in nematode juveniles, where the recorded values were $11.97,10.80 \%$ and $9.32 \%$ at the three tested periods, respectively; with insignificant differences among them and this result was in agreement with El-Badawy (2002) who reported that in the nematode $H$. bacteriophora ( $\mathrm{N}-1$ strain), during a 50day period, total carbohydrates were of minor importance as energy reserves.

\section{4- Glycogen content}

Estimation of glycogen content as an energy reserve in nematode juveniles of the three species at the tested ages table (7) indicated that this component has minor role as energy reserve. The glycogen recorded values of $S$. riobrave were $8.30,8.09$ and $7.93 \%$ of nematode dry weight at 0,20 and 90-day old juveniles, respectively. The four species (S. carpocapsae, S. riobravis (Biosys 355), S. feltiae (UK76) and $S$. glaseri (NC) had appreciable amounts of glycogen; from ca. $8 \%$ dry weight in $S$. riobravis to ca. $18 \%$ in S. glaseri (Patel and Wright 1997). Lewis et. al. (1995) reported that level of glycogen remained constant for S. glaseri, S. carpocapase and H. bacteriophora at approximately $7.80 \%$. 
In case of $H$. indica during the first two ages, a slight insignificant decrease was found in glycogen content (from 7.35 to $7.25 \%$ ), but at 40 -day old juvenile, significant decrease was recorded (5.00\% of nematode dry weight). The recorded values of $H$. bacteriophora exhibited an insignificant decrease after 30 days from (7.45\%) to reach $7.23 \%$ and slight significant decrease was recorded at 50 days (6.17\%). Infective juveniles of $S$. carpocapsae and $S$. riobravis survived for 120-135 days and utilized ca. $90 \%$ of their glycogen reserve at an almost constant rate during a 112-day storage period (Patel and Wright 1997). On the other hand, Wright et. al., (1997) demonstrated that glycogen content declined significantly between 60 and 90 days of storage in the nematode $S$. carpocapsae, this decline began after 90 days in S. feltiae. These obtained findings support the conclusion of (Patel \& Wright 1997). S. carpocapsae IJs not only consumed the lipid reserve but also proteins, glycogen and trehalose. Most lipids were consumed in the first three weeks while most of the proteins, trehalose and glycogen were consumed in the next three weeks. The results of glycogen in the present study and those of Patel and Wright (1997) and Wright et. al. (1997) suggest that glycogen content may be utilized as an alternative energy reserve in nematode juveniles after a considerable storage period after the lipid reserves reaches a certain level

There are different relationships between infectivity, penetration, migration rates and energy utilization. Infectivity was not affected by the declining of total lipids content (Tables 1 and 4). This is in agreement with Qiu and Bedding (2000) who indicated that infectivity of $S$. carpocapsae IJs, did not significantly decrease until nearly all lipids were consumed. This finding disagree with Patel and Wright (1997) who found that, three nematodes species ( $S$. riobrave, $S$. feltiae and $S$. glaseri) showed a rapid initial decline in infectivity with declining lipid levels and Lewis et. al. (1995) in most species of EPN, activity and infectivity decline as lipids were depleted. This may be explained by the behavior of $S$. riobravis where, switching to ambushing with relatively high lipid levels remaining, matching its labeling as an intermediate ambusher.

Penetration rate of $\boldsymbol{H}$. indica, and $\boldsymbol{H}$. bacteriophora decreased with the decreasing of the total lipid content at the three tested juvenile ages. The values of penetration rate of $S$. riobrave approximately were similar at the two juvenile ages ( 0 day and 20 days) also, total lipid content not changed at the same two juvenile ages (Tables 2 and 4). El-Assal et. al. (2008) showed that the highest penetration rate of S. riobravis was recorded with the highest total lipids content. Increased energy consumption will subsequently shorten the life of the non-feeding IJs. Hence, unsuccessful penetration attempts must be costly. $\mathrm{H}$. indica was more declining in penetration rate than $S$. riobrave at the tested juvenile ages while, $H$. bacteriophora was the highest. This result may be explained by the fact that greater aggregation occurs in 
Heterorhabditids than in steinernematids, decreasing oxygenation and leading to the loss of energy reserves could be a factor that maintained nematodes of the genus Heterorhabditis alive for a shorter time. However, the ability of the three strains of nematodes to penetrate the host decreased as the lipid content decreased throughout all tested juvenile ages. These findings of infectivity and penetration rate may support the concept that the virulence of any nematode isolate is, most probably, due to the pathogenicity of the bacterial symbiont. Entmopathogenic nematodes without bacteria did not kill insect larvae, and the infectivity of the nematode-bacterial combination was determined by the pathogenicity of the bacterium and by the interaction between them.

Results in tables ( 3 and 4 ) showed that, there was decreasing in the migration rate of the three juvenile ages of $H$. bacteriophora and $H$. indica, with reduction of total lipid content. The ability of the two nematodes to migrate decreased as lipid content decreased throughout all tested juvenile ages. Where, penetration and migration rates were affected with the values of lipid content, persistence and pathogenicity of entomopathogenic nematodes is associated with lipid content.

Carbohydrates of $S$. riobravis during the first 20 days were important sources for energy besides total lipids, (Tables 4 and 6). This result is confirmed by Kung et. al. (1990) who showed that energy generated of $S$. carpocapsae and $S$. glaseri by carbohydrate consumption from stored food reserves was used up rapidly, resulting in low survival, motility and pathogenicity.

Carbohydrates appeared to be source of energy only when juveniles get older in $H$. indica and $H$. bacteriophora. This conclusion is confirmed by (Patel and Wright 1997). who reported that carbohydrate might be important for infectivity in aging IJs of $S$. carpocapsae.. and also, Qiu and Bedding (2000) stated that most lipids were consumed in the first 3 weeks while most proteins, glycogen and trehalose were consumed in the last 2 or 3 weeks.

The importance of glycogen and protein as energy sources has not been investigated for three EPN strains at the three tested juvenile ages. The results of glycogen in the present study and those of Patel and Wright (1997) and Wright et. al. (1997) suggest that glycogen content may be utilized as an alternative energy reserve in nematode juveniles after a considerable storage period after the lipid reserves reaches a certain level. Glycogen was shown to be important in maintaining infectivity in aged IJs of S. carpocapsae Patel and Wright (1997) and Wright et. al. (1997). Glycogen and trehalose levels of $S$. carpocapsae were maintained during the first 3 weeks of incubation when lipids had not been severely depleted (Qiu and Bedding 2000). 


\section{CONCLUSION}

Total lipids suggested to be the main source of energy in EPN juveniles that depend upon it in searching and penetrating hosts, and the consumption of these reserves resulted in the observed decrease in nematode efficiency. Total protein and glycogen might play minor role as utilizable energy reserves, while, total carbohydrates appeared to only utilized early in the ambushing state of $S$. riobrave, and when juveniles get older in $H$. indica and $H$. bacteriophora. Obtained results in the present study might be helpful in the field nematodes production which is rich of the most consumable energy reserves and thus improving their shelf-life, their quality and consequently their value as biological control agents of insect pests. Also, establishing a simple and easy quality control method for different nematode species or strains.

Table 1. Infectivity of $S$. riobrave, $H$. indica and $H$. bacteriophora to $G$. mellonella larvae at different juvenile ages.

\begin{tabular}{|c|c|c|c|}
\hline \multirow{2}{*}{ Juvenile age (days) } & \multicolumn{3}{|c|}{$\%$ Galleria mortality (Mean \pm SEM) } \\
\cline { 2 - 4 } & S. riobrave & H. indica & H. bacteriophora \\
\hline 0 or less than one week* & $100 \pm 0.00^{\mathrm{a}}$ & $100 \pm 0.00^{\mathrm{a}}$ & $100 \pm 0.00^{\mathrm{a}}$ \\
\hline 20 or $30^{* *}$ & $100 \pm 0.00^{\mathrm{a}}$ & $100 \pm 0.00^{\mathrm{a}}$ & $99.0 \pm 3.00^{\mathrm{a}}$ \\
\hline 40 or $90^{* * *}$ & $100 \pm 0.00^{\mathrm{a}}$ & $97.33 \pm 3.33^{\mathrm{a}}$ & $100 \pm 0.00^{\mathrm{a}}$ \\
\hline
\end{tabular}

Table 2. Penetration rate of $\mathrm{S}$. riobrave, $\mathrm{H}$. indica and $\mathrm{H}$. bacteriophora to $\mathrm{G}$. mellonella larvae at different juvenile ages.

\begin{tabular}{|c|c|c|c|}
\hline \multirow{2}{*}{ Juvenile age (days) } & \multicolumn{3}{|c|}{ \% Penetration (Mean \pm SEM) } \\
\cline { 2 - 4 } & S. riobrave & H. indica & H. bacteriophora \\
\hline 0 or less than one week* & $25.10 \pm 2.02^{\mathrm{a}}$ & $21.70 \pm 1.80^{\mathrm{a}}$ & $40.09 \pm 2.46^{\mathrm{a}}$ \\
\hline 20 or $30^{* *}$ & $24.75 \pm 2.88^{\mathrm{a}}$ & $13.00 \pm 3.00^{\mathrm{b}}$ & $8.55 \pm 0.65^{\mathrm{b}}$ \\
\hline 40 or $90^{* * *}$ & $22.80 \pm 2.38^{\mathrm{b}}$ & $11.50 \pm 2.50^{\mathrm{b}}$ & $7.05 \pm 1.15^{\mathrm{b}}$ \\
\hline
\end{tabular}

Table 3. Migration rates of $\mathrm{H}$. indica and $\mathrm{H}$. bacteriophora at different juvenile ages

\begin{tabular}{|c|c|c|c|c|}
\hline \multirow{2}{*}{ Juvenile age (days) } & \multicolumn{2}{|c|}{$\%$ Migration (Mean \pm SEM) } & \multicolumn{2}{l|}{ Distance traveled (cm) } \\
\cline { 2 - 5 } & H. indica & $\begin{array}{c}\text { H. } \\
\text { bacteriophora }\end{array}$ & H. indica & $\begin{array}{c}\text { H. } \\
\text { bacteriophora }\end{array}$ \\
\hline 0 or less than one week* & $96.55 \pm 2.1^{\mathrm{a}}$ & $98.88 \pm 4.35^{\mathrm{a}}$ & $9.20 \pm 0.56^{\mathrm{a}}$ & $9.5 \pm 0.20^{\mathrm{a}}$ \\
\hline 20 or $30^{* *}$ & $25.75 \pm 1.8^{\mathbf{b}}$ & $78.77 \pm 0.05^{\mathrm{a}}$ & $2.80 \pm 0.59^{\mathrm{b}}$ & $8.00 \pm 1.2^{\mathbf{b}}$ \\
\hline 40 or $50^{* * *}$ & $15.97 \pm 0.59^{\mathrm{c}}$ & $38.4 \pm 11.00^{\mathrm{b}}$ & $1.10 \pm 0.59^{\mathrm{c}}$ & $1.90 \pm 0.4^{\mathrm{c}}$ \\
\hline
\end{tabular}

Table 4. Lipid content of $\mathrm{S}$. riobrave $\mathrm{H}$. indica and $\mathrm{H}$. bacteriophora at different juvenile ages.

\begin{tabular}{|c|c|c|c|}
\hline \multirow{2}{*}{ Juvenile age (days) } & \multicolumn{3}{|c|}{ \% Lipid content (Mean \pm SEM) } \\
\cline { 2 - 4 } & S. riobrave & H. indica & H. bacteriophora \\
\hline 0 or less than one week* & $42.55 \pm 0.29^{\text {a }}$ & $53.75 \pm 0.54^{\text {a }}$ & $50.52 \pm 0.34^{\text {a }}$ \\
\hline 20 or $30^{* *}$ & $41.95 \pm 1.13^{\text {a }}$ & $37.39 \pm 0.77^{\text {b }}$ & $22.45 \pm 0.77^{\mathrm{b}}$ \\
\hline 40 or 50 or $90^{* * *}$ & $18.00 \pm 2.00^{\mathbf{b}}$ & $25.51 \pm 0.34^{\mathrm{c}}$ & $16.00 \pm 0.34^{\mathrm{c}}$ \\
\hline
\end{tabular}

Values are expressed as dry weight \% of total lipid content 
Table 5. Protein content of $S$. riobrave and $H$. indica and $H$. bacteriophora different juvenile ages.

\begin{tabular}{|c|c|c|c|}
\hline \multirow{2}{*}{ Juvenile age (days) } & \multicolumn{3}{|c|}{$\%$ Protein content (Mean \pm SEM) } \\
\cline { 2 - 4 } & S. riobrave & H. indica & H. bacteriophora \\
\hline 0 or less than one week* & $11.30 \pm 0.99^{\mathrm{a}}$ & $11.80 \pm 0.51^{\mathrm{a}}$ & $11.25 \pm 0.15^{\mathrm{a}}$ \\
\hline 20 or $30^{* *}$ & $11.20 \pm 1.00^{\mathrm{a}}$ & $12.00 \pm 0.31^{\mathrm{a}}$ & $11.00 \pm 0.01^{\mathrm{a}}$ \\
\hline 40 or 50 or $90^{* * *}$ & $11.20 \pm 1.00^{\mathrm{a}}$ & $12.10 \pm 0.79^{\mathrm{a}}$ & $10.96 \pm 0.30^{\mathrm{a}}$ \\
\hline
\end{tabular}

Values are expressed as dry weight $\%$ of total protein content.

Table 6. Carbohydrate content of S. riobrave , H. indica and H. bacteriophora at different juvenile ages

\begin{tabular}{|c|c|c|c|}
\hline \multirow{2}{*}{ Juvenile age (days) } & \multicolumn{3}{|c|}{$\%$ Carbohydrate content (Mean \pm SEM) } \\
\cline { 2 - 4 } & S. riobrave & H. indica & H. bacteriophora \\
\hline 0 or less than one week* & $23.43 \pm 0.30^{\mathrm{a}}$ & $13.94 \pm 0.29^{\mathrm{a}}$ & $11.97 \pm 0.06^{\mathrm{a}}$ \\
\hline 20 or $30^{* *}$ & $16.33 \pm 0.37^{\mathrm{b}}$ & $11.84 \pm 0.16^{\mathrm{b}}$ & $10.80 \pm 0.04^{\mathrm{b}}$ \\
\hline 40 or 50 or $90^{* * *}$ & $14.28 \pm 0.50^{\mathrm{b}}$ & $8.25 \pm 0.19^{\mathrm{c}}$ & $9.32 \pm 0.17^{\mathrm{c}}$ \\
\hline
\end{tabular}

Values are expressed as dry weight \% of total carbohydrates content.

Table 7. Glycogen content of S. riobrave . $\mathrm{H}$. indica and $\mathrm{H}$. bacteriophora at different juvenile ages

\begin{tabular}{|c|c|c|c|}
\hline \multirow{2}{*}{ Juvenile age (days) } & \multicolumn{3}{|c|}{$\%$ Glycogen content (Mean \pm SEM) } \\
\cline { 2 - 4 } & S. riobrave & H. indica & H. bacteriophora \\
\hline 0 or less than one week* & $8.30 \pm 0.97^{\mathrm{a}}$ & $7.55 \pm 0.15^{\mathrm{a}}$ & $7.45 \pm 0.15^{\mathrm{a}}$ \\
\hline 20 or $30^{* *}$ & $8.09 \pm 1.00^{\mathrm{a}}$ & $7.29 \pm 0.12^{\mathrm{a}}$ & $7.23 \pm 0.12^{\mathrm{a}}$ \\
\hline 40 or 50 or $90^{* * *}$ & $7.90 \pm 1.05^{\mathrm{a}}$ & $5.00 \pm 0.06^{\mathrm{b}}$ & $6.17 \pm 0.06^{\mathrm{a}}$ \\
\hline
\end{tabular}

Values are expressed as dry weight \% of total glycogen.

SEM = Standard error of the mean.

* 0 days for $H$. indica; and $S$. riobrave and less than one week for $H$. bacteriophora.

** 20 days for $H$. indica; and $S$. riobrave, 30 days for $H$. bacteriophora.

*** 40 days for $H$. indica; 50 days for $H$. bacteriophora and 90 days for $S$. riobrave.

$\mathbf{\%}$ total lipids, protein, carbohydrates, glycogen in nematode sample $=\mathbf{X} / \mathbf{Y x 1 0 0}$

$\mathbf{X}=$ weight of lipid, protein, carbohydrates, glycogen per $\mathrm{mg}$

$\mathbf{Y}=$ weight of nematode sample per $\mathrm{mg}$

For each nematode species, means followed by the same letter are not significantly different $(P<0.05$;

Duncan's multiple range test). 


\section{REFERENCES}

1. Abbott, W.S. 1925. A method for computing the effectiveness of an insecticide. J. Econ. Entomol., 18: 265-267.

2. Abd-El-Rahman, R.M. 2001. Studies on the entomopathogenic nematodes of family Rhabditidae from Egypt. Ph.D. Thesis, Fac. Science, Cairo University, 125 pp.

3. Abu Hatab, M.A. and Gaugler, R. 1997a. Influence of growth temperature on fatty acids and phospholipids of Steinernema. riobravis infective juveniles. J. Them. Biol., 22: 237-244.

4. Bradford, M.N. 1976. A rapid and sensitive method for the quantification of microgram quantities of protein utilizing the principle protein-dye binding. Annal. Biochem., 72: 248-54.

5. Corrie, A., S. Yoder, R. Grewal and J. Taylor. 2004. Rapid age-related changes in infection behavior of entomopathogenic nematodes, Journal of Parasitology 90(6):1229-1234.

6. Dubois.M., K.A. Giles., J.A. Hamilton., P.A. Rebers. and S. Red. 1956. Colometric method for determination of sugars and related substances. Analytical. Chem. V28 No..3 350-356.

7. El-Assal, F.M.,.. S. F. El-Lakwah, W. S. Hasheesh and M. El-Mahdi. 2008. Effect of the change in energy reserves on the entomopathogenic nematode efficacy. J Egypt Soc Parasitol. Dec;38(3):929-44

8. El-Badawy, S.S.M. 2002. Organic chemical studies on some natural enemies of insect pests. M.Sc. Thesis, Fac. Sci., Al-Azhar Univ., 76 pp.

9. El-Bishry, M.H., F.M. El-Assal and R.M. Abe El-Rahman. 2002. Factors affecting penetration rate of entomopathogenic nematodes Heterorhabditis spp. Egypt. J. Biol. Pest Cont., 12 (1): 25-38.

10. Fitters P. F. and C.T. Griffin. 2006. Survival, starvation, and activity in Heterorhabditis megidis (Nematoda: Heterorhabditidae), Biological Control 37 82-88.

11. Fitters, P.F.L., Meijer, E.M.J., D.J. Wright, and C.T. Griffin. 1997. Estimation of lipid reserves in unstained living and dead nematodes by image analysis Journal of nematology (USA).June 1997. V. 29(2) P: 160-167.

12. Folch, .J., M. Lees and G. Sloane-Stanly. 1957. A simple method for the isolation and purifications of total lipids from animal tissues. J.of Biological Chem. 226: 497-509. 
13. Kaya, H.K. and S.P. Stock. 1997. Techniques in insect nematology. In: Lacey LA, editor. Manual of Techniques in Insect Pathology. San Diego, CA: Academic Press;. pp. 281-324

14. Knight, J.A., Anderson and J.A. rode. 1972. Chemical basis of sulfuricphosphovanillin reaction for estimation of total lipids. Clinical. Chemistry., Vol.18: 199-202.

15. Kung, S. P. , R. Gaugler and Kaya, H.Y K. 1990. Influence of Soil pH and Oxygen on Persistence of Steinernema spp. Journal of Nematology 22(4):440-445.

16. Lewis, E.E., J.F. Campbell and R.Gaugler. 1997. The effects of aging on the foraging behaviour of Steinernema carpocapsae (Rhabditida: Steinernematidae). Nematologica, 43: 355-362.

17. Lewis, E.E., S. Selvan, J.F. Campbell and R. Gaugler. 1995. Changes in foraging behavior during the infective stage of entomopathogenic nematodes. Parasitology 110, 583-590.

18. Menti, H., M.N.Patel, D.J. Wright and R.N. Perry. 2003. Lipid utilisation during storage of the entomopathogenic nematodes Steinernema feltiae and Heterorhabditis megidis from Greece and the UK Nematology, Volume 5, Number 1, pp. 31-37(7)

19. Patel, M.N. and D.J. Wright. 1997. Glycogen: its importance in the infectivity of the aged juveniles of Steinernema carpocapsae. Parasitology 114, 591-596

20. Qiu, L. and R. Bedding. 2000. Energy metabolism and its relation to survival and infectivity of infective juveniles of Steinernema carpocapsae under aerobic conditions. Nematology 2, 551-559.

21. Radwan, H. M. 2002. Biochemical studies on some entomopathogenic nematodes. M.Sc. Thesis, Fac. Agri, Cairo Univ., 44-46 pp.

22. Shapiro-Ilan, D. I., J. D. Dutcher and M. Hatab. 2005. Recycling Potential and Fitness of Steinernematid Nematodes Cultured in Curculio caryae and Galleria mellonella Journal of Nematology 37(1):12-17

23. Wright, D.J., P.S. Grewal and M. Stolinski. 1997. Relative importance of neutral lipids and glycogen as energy stores in dauer larvae of two entomopathogenic nematodes. Comparative biochemistry and physiology. Part-B, Biochemistry and molecular biology (USA). V. 118B (2): 269-273. 


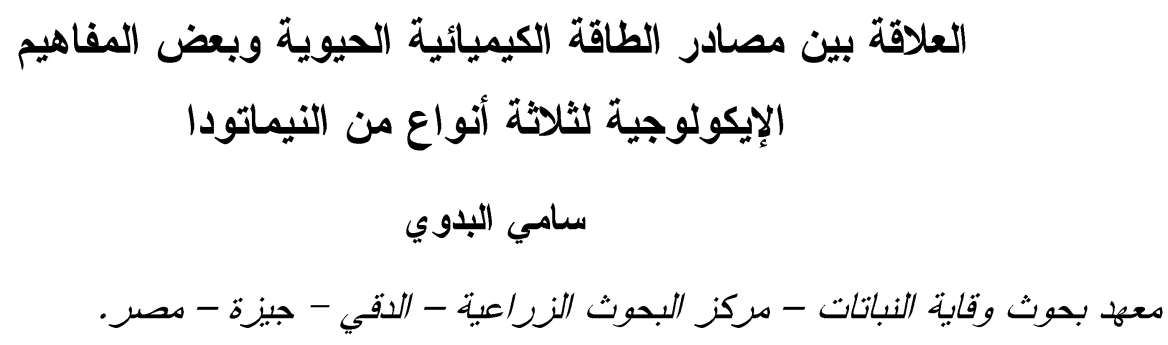

يهدف هذا البحث إلي التحليل الكامل لمستودعات الطاقة الكيميائية الحيوية ( اللبيدات ، البروتين ،

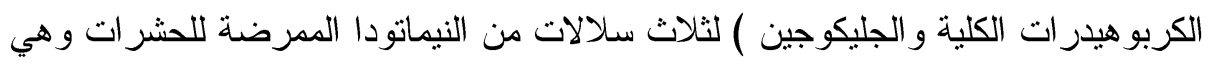
Steinernema riobrave Heterorhabditis

H. ثلاث أعمار للنيمانودا (صفر،20،90 يوم) لسلالة S. riobravae indica

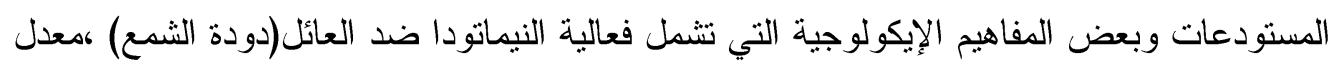

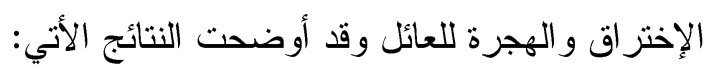
ا باللبيدات هي المصدر الرئيسى للطاقة للثلاث سلالات من النيماتودا خلال كل الأعمار .

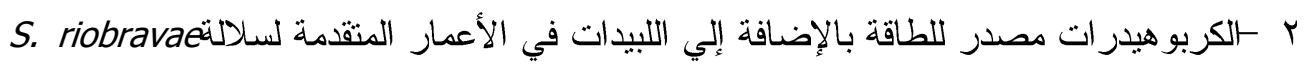

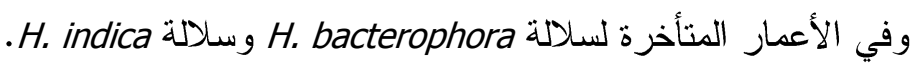
ب -البروتين و الجليكوجين لهما تأثير ثانوي كمصدر للطاقة في الثناث سلالات خلاد كل كل الأعمار . ع - فعالية النيماتودا (إصابة العائل وقتله) لم تتأثر بمحتوي اللبيدات بالزيادة أو النقصان لمان وكانت نسبة الموت لدودة الثمع تقريباُ 100\% موت مع سلالات النيماتودا الثلاثة مع كل الأعمار

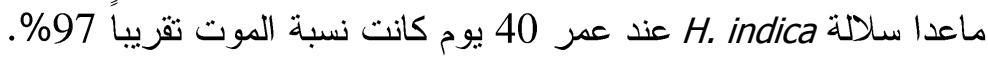

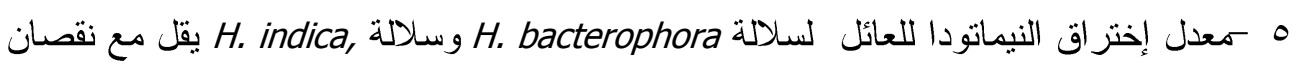
البيدات الكلية في كل الأعمار المختلفة بينما يحدث ذلك فقط مع سلالة S. riobravae عمر 90 يوم.

1 H. bacterophora معدل هجرة النيماتودا للعائل تزيد كلما زاد محتوي اللبيدات في سلالة وسلالة H. indica مع الأعمار الثلاثة.

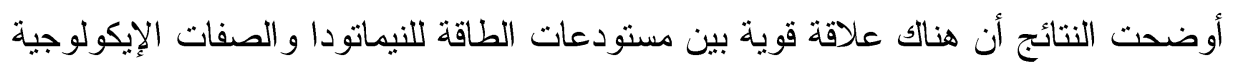
و هذه النتائج يمكن أن تساعد في زيادة كفاءة النيماتودا كوسيلة مكافحة حيوية ضد الأفات عن طريق تحسين و إطالةعمر النيماتودا و أيضاً إيجاد طريقة سهلة وبسيطة للتحكم في جودة سلالات النيماتودا 